\section{A comparison of periodontal disease among rural Amish and non-Amish adults}

\author{
Bagramian RA, Farghaly MM, Lopatin D, Sowers MF, Syed SA and Pomerville \\ JL: A comparison of periodontal disease among rural Amish and non-Amish adults. \\ J Clin Periodontol 1994; 21: 386-390. (C) Munksgaard, 1994.
}

Abstract. Periodontal disease can be more efficiently studied within a homogeneous population where genetic influences and lifestyles are similar enough to negate their effect on the disease process. This study focuses on an Amish population in southern Michigan who isolate themselves from outside influences and their non-Amish neighbors. A total of 425 Amish and 290 non-Amish were contacted resulting in 330 Amish and 215 non-Amish who were examined in their homes giving a participation rate of $76.2 \%$. Ages ranged from 18 to 82 years. Prevalence of periodontal disease tended to be higher among males and increased with age. There were slightly more Amish females (52\%) than non-Amish (49\%). Means of periodontal conditions for Amish were $1.35 \mathrm{~mm}$ for attachment loss, 2.59 $\mathrm{mm}$ for pocket depth, 0.24 for calculus, 0.77 for plaque and 0.74 for gingivitis. For non-Amish, the means were $1.03 \mathrm{~mm}$ for attachment loss, $2.38 \mathrm{~mm}$ for pocket depth, 0.40 for calculus, 0.95 for plaque and 0.87 for gingivitis. It is of interest that the Amish do not practice routine oral hygiene. Only $36.8 \%$ of Amish reported brushing at least $1 \times$ a day compared to $84.6 \%$ of non-Amish. Similarly, only $8.2 \%$ of Amish reported flossing at least $1 \times$ a week compared to $40.8 \%$ of non-Amish.
Robert A. Bagramian', Mahassen M. Farghaly ${ }^{1}$, Dennis Lopatin', MaryFran Sowers ${ }^{2}$, Salam A. Syed ${ }^{1}$ and Julie L. Pomerville ${ }^{1}$

${ }^{1}$ School of Dentistry, University of Michigan; ${ }^{2}$ School of Public Health, University of Michigan, Ann Arbor, Michigan 48109-1078
Key words: Amish; periodontal disease; prevalence; epidemiology; attachment loss. Accepted for publication 21 July 1993
The Amish in this study isolate themselves from the outside world by living without electricity, telephones, or automobiles and marrying within their society. As reported previously (Bagramian et al. 1992), the Amish maintain a secluded lifestyle as a result of religious values established in the 16th century in Switzerland. The extent of isolation and self-sufficiency of the Amish community is demonstrated by the existence of Amish schools, which children attend to 8 th grade. Only a few of the Amish, $8 \%$, in this study completed high school in public schools. Households of 10 or more comprising extended family members are common (McKusick 1980, Hostetler 1980). This secluded population provides a unique opportunity to investigate the impact of a variety of factors on prevalence of periodontal disease.

Low levels of periodontal disease found among the Amish in pilot studies
(Bagramian et al. 1988) formed the basis for the present intensive study. Our previous paper assessed dental examinations conducted on an Amish farming community during the 2-year period 1989-90. The purpose of this paper is to report periodontal disease data collected for Amish $(N=330)$ and nonAmish controls $(N=215)$ over the entire 3-year period, 1989-91. Assessments of behavior, attitudes toward oral hygiene, and knowledge of periodontal disease are examined along with various measures of periodontal disease.

\section{Methods}

Amish farms are interspersed with nonAmish farms in the area targeted for this study. A map of the Amish community identified Amish and non-Amish farms. Letters were mailed to all area residents informing them of our study and sol- iciting participation. The 2 populations were approached in as similar a fashion as possible. For Amish respondents, several steps were involved in gaining entry into individuals' homes to conduct the interview and exam. The 1st entry point was the religious leaders called Bishops. Each Bishop has responsibility for apprixmately 30 Amish families and has ultimate authority over access to Amish. After receiving a Bishop's approval, the team was able to contact individual families, where the 2nd entry point was the head of the household. Once the household head agreed, the investigators were free to solicit participation of individual family members.

Since Amish participants were recruited door-to-door, non-Amish were also recruited door-to-door. Every nonAmish house was approached to ensure the sample was as similar to the Amish as possible. Unlike the Amish, these in- 
dividuals could be accessed directly. Solicitations were made during the evening as well as the daytime to avoid biasing the sample.

A total of 425 adult Amish men and women over 18 years of age were contacted and of these, 330 were examined, giving a $77.6 \%$ response rate. Of the 290 non-Amish contacted, 215 responded, a response rate of $74.1 \%$. All subjects were reimbursed for participation and no dental treatment was provided. Conditions similar to the field were used to calibrate 3 examiners to a reference periodontist, and $x$-statistics between each of the examiners were calculated for level of agreement on attachment loss and pocket depth. For attachment loss the $\chi$ s ranged from 0.64 to 0.70 , and for pocket depth, they ranged from 0.90 to 0.93 , well within the limits in other studies and national surveys (Brown et al. 1989).

Electricity was not available in homes, requiring examinations to be performed with a battery operated head light and portable dental chair. Measurements were taken from 6 standard sites of all existing teeth except $3 \mathrm{rd}$ molars: distal-buccal, mid-buccal, mesiobuccal, disto-lingual, mid-lingual and mesio-lingual. The following indices were included: Silness \& Löe (1964) plaque index, Löe \& Silness (1963) gingival index, Ramfjord (1976) calculus index, and modified Ramfjord (1976) PDI for pocket depth and attachment loss measurements. A Hu-Friedy no. 11 periodontal probe was employed to measure loss of periodontal attachment and pocket depth to the nearest millimeter.

A 1-h, comprehensive questionnaire was administered by a trained interviewer. Items regarding demographic characteristics, former health problems, current medications, allergies, tobacco use, frequency of physician visits, and family oral health history provided an overall picture of the respondents' general health. Oral health attitudes and practices were probed through a series of questions on the respondent's oral health history, recent dental care, daily oral hygiene habits and satisfaction with dental services. The 23-page instrument was pre-tested on adult patients at the University of Michigan School of Dentistry over a 3-week period. Internal validity was checked through repetitive questions with altered wording or a reverse response and modified.

A knowledge score was computed based on 8 questions that evaluated the respondent's ability to define periodontal disease. An index of oral hygiene was also created from 4 questions dealing with brushing, flossing, rinsing, and periodontal disease.

Severity of periodontal disease was examined to identify differences for Amish compared to controls by identifying the proportion of people with $\geqslant 1$ site at various disease levels (Kingman et al. 1988) and by assessing wholemouth means. Disease was delineated as having $\geqslant 1$ tooth with $4 \mathrm{~mm}$ of attachment loss or $5 \mathrm{~mm}$ of pocket depth or a mean greater than $1.5 \mathrm{~mm}$ attachment loss or $3.0 \mathrm{~mm}$ pocket depth.

Logistic regression was applied to determine the relationship between explanatory variables: age, gender, Amish or non-Amish, oral health care; knowledge of periodontal disease, whether or not the person had mean plaque or mean gingivitis scores $>1$ or mean calculus scores $>0$; and presence or absence of disease. Each explanatory variable was entered into the model sequentially to determine the extent of any additional impact on the model ability to predict the probability of disease. Interactions between explanatory variables were also entered into the model. Variables that did not show a significant dependent relationship with independent variables, as evidenced by the $p$ values for the Wald $\chi^{2}$ statistic, were dropped from the model. This iterative process resulted in identification of explanatory variables that significantly relate to periodontal disease. Odds ratios were calculated.

\section{Results}

Amish respondents were younger (81\% under 45) than non-Amish (54\% were under 45) and less educated; $8 \%$ had a 12 th grade education compared to $50 \%$ of non-Amish. There were slightly more

female Amish (52\%) than males (48\%). Gender for non-Amish was almost evenly split with $49 \%$ female and $51 \%$ male.

A larger proportion of non-Amish had a full dentition at all age levels except for ages 25-34 years (Tables 1,2). While $64 \%$ of Amish age 18-24 years had a full dentition, $78 \%$ of non-Amish at this age had all of their teeth. Similarly, only $10 \%$ of Amish over 55 years had a full dentition while $19 \%$ of nonAmish of this age had all of their teeth. The mean number of teeth present, however, differed little except for the age group 45-54 years, where the mean was 19.2 for Amish and 24.2 for nonAmish.

Mean attachment loss for Amish was $1.35 \mathrm{~mm}$ while mean pocket depth was $2.59 \mathrm{~mm}$. For non-Amish, the means were slightly lower: $1.03 \mathrm{~mm}$ for attachment loss and 2.38 for pocket depth. Mean calculus scores were low with an overall mean of 0.24 for Amish and 0.40 for non-Amish. Plaque and gingivitis means showed somewhat higher levels but were still relatively low: 0.77 and 0.74 for Amish and 0.95 and 0.87, respectively, for non-Amish.

Among Amish, females had lower attachment loss levels than males at every age except the youngest. Gingivitis and plaque showed similar age- and gender-related increases, while the change in pocket depth levels was not as dramatic. For Amish, attachment loss rose from $0.96 \mathrm{~mm}$ at $18-24$ years to $2.18 \mathrm{~mm}$ at age 54 years and above (Table 3). For non-Amish, attachment loss levels increased consistently with age from $0.68 \mathrm{~mm}$ at $18-24$ years to 1.69 at age 54 and above (Table 4$)$.

The distributions for oral hygiene practices and knowledge of periodontal disease showed significant differences between Amish and non-Amish respondents. Given their secluded life style, the Amish performed as expected, scoring lower than non-Amish on the identifi-

Table 1. \% distribution of numbers of teeth and mean number of teeth by age among Amish

\begin{tabular}{lccccc}
\hline \multicolumn{5}{c}{$\begin{array}{c}\text { Age group } \\
\text { (years) }\end{array}$} \\
\cline { 2 - 6 } No. Teeth & $18-24$ & $25-34$ & $35-44$ & $45-54$ & $55+$ \\
$(N=111)$ & $(N=82)$ & $(N=69)$ & $(N=28)$ & $(N=40)$ \\
\hline $5-10$ & 0.0 & 0.0 & 2.9 & 14.3 & 10.0 \\
$11-19$ & 0.9 & 0.0 & 11.6 & 21.4 & 17.5 \\
$20-27$ & 35.1 & 48.8 & 65.2 & 60.7 & 62.5 \\
$28+$ & 64.0 & 51.2 & 20.3 & 3.6 & 10.0 \\
\hline mean no. of teeth & 27.3 & 26.6 & 23.6 & 19.2 & 20.8 \\
\hline
\end{tabular}


Table 2. \% distribution of numbers of teeth and mean number of teeth by age among non-Amish

\begin{tabular}{lccccc}
\hline No. teeth & $18-24$ & $25-34$ & $35-44$ & $45-54$ & $55+$ \\
$(N=23)$ & $(N=47)$ & $(N=47)$ & $(N=40)$ & $(N=58)$ \\
\hline $5-10$ & 0.0 & 0.0 & 2.1 & 2.5 & 12.1 \\
$11-19$ & 0.0 & 2.1 & 4.3 & 7.5 & 15.5 \\
$20-27$ & 21.7 & 53.2 & 59.6 & 70.0 & 53.4 \\
$28+$ & 78.3 & 44.7 & 34.0 & 20.0 & 19.0 \\
\hline Mean no teeth & 27.6 & 26.7 & 25.2 & 24.2 & 21.6 \\
\hline
\end{tabular}

Table 3. Mean periodontal disease measures by age among Amish

\begin{tabular}{|c|c|c|c|c|c|c|}
\hline \multirow[b]{2}{*}{ Index } & \multicolumn{5}{|c|}{$\begin{array}{l}\text { Age group } \\
\text { (years) }\end{array}$} & \multirow[b]{2}{*}{$\begin{array}{c}\text { Total } \\
(N=545)\end{array}$} \\
\hline & $\begin{array}{c}18-24 \\
(N=111)\end{array}$ & $\begin{array}{c}25-34 \\
(N=82)\end{array}$ & $\begin{array}{c}35-44 \\
(N=69)\end{array}$ & $\begin{array}{c}45-54 \\
(N=28)\end{array}$ & $\begin{array}{c}55+ \\
(N=40)\end{array}$ & \\
\hline plaque & 0.72 & 0.72 & 0.74 & 0.97 & 1.00 & 0.77 \\
\hline calculus & 0.17 & 0.19 & 0.22 & 0.41 & 0.44 & 0.24 \\
\hline gingivitis & 0.66 & 0.74 & 0.77 & 0.85 & 0.86 & 0.74 \\
\hline pocket depth & 2.54 & 2.64 & 2.68 & 2.59 & 2.54 & 2.59 \\
\hline attachment loss & 0.96 & 1.28 & 1.48 & 1.78 & 2.18 & 1.35 \\
\hline
\end{tabular}

Table 4. Mean periodontal disease measures by age among non-Amish

\begin{tabular}{|c|c|c|c|c|c|c|}
\hline \multirow[b]{2}{*}{ Index } & \multicolumn{5}{|c|}{$\begin{array}{l}\text { Age group } \\
\text { (years) }\end{array}$} & \multirow[b]{2}{*}{$\begin{array}{c}\text { Total } \\
(N=545)\end{array}$} \\
\hline & $\begin{array}{c}18-24 \\
(N=23)\end{array}$ & $\begin{array}{c}25-34 \\
(N=47)\end{array}$ & $\begin{array}{c}35-44 \\
(N=47)\end{array}$ & $\begin{array}{c}45-54 \\
(N=40)\end{array}$ & $\begin{array}{c}55+ \\
(N=58)\end{array}$ & \\
\hline plaque & 0.65 & 0.88 & 1.00 & 0.84 & 1.12 & 0.95 \\
\hline calculus & 0.11 & 0.35 & 0.46 & 0.34 & 0.47 & 0.40 \\
\hline gingivitis & 0.65 & 0.88 & 0.93 & 0.75 & 1.04 & 0.87 \\
\hline pocket depth & 2.42 & 2.48 & 2.45 & 2.29 & 2.43 & 2.38 \\
\hline attachment loss & 0.68 & 0.78 & 0.85 & 0.89 & 1.69 & 1.03 \\
\hline
\end{tabular}

Table 5. \% distribution for attachment loss of $\geqslant 4 \mathrm{~mm}$ by age for Amish and non-Amish

\begin{tabular}{|c|c|c|c|c|c|c|c|c|}
\hline \multirow{4}{*}{$\begin{array}{l}\text { Age } \\
\text { (years) }\end{array}$} & \multicolumn{8}{|c|}{ Attachment loss } \\
\hline & \multicolumn{4}{|c|}{ Amish } & \multicolumn{4}{|c|}{ Non-Amish } \\
\hline & \multicolumn{2}{|c|}{$\leqslant 4 \mathrm{~mm}$} & \multicolumn{2}{|c|}{$\geqslant 4 \mathrm{~mm}$} & \multicolumn{2}{|c|}{$\leqslant 4 \mathrm{~mm}$} & \multicolumn{2}{|c|}{$\geqslant 4 \mathrm{~mm}$} \\
\hline & $N$ & $\%$ & $N$ & $\%$ & $N$ & $\%$ & $N$ & $\%$ \\
\hline $18-24$ & 73 & 65.8 & 38 & 34.2 & 19 & 86.4 & 4 & 13.6 \\
\hline $25-34$ & 30 & 36.6 & 52 & 63.4 & 27 & 57.5 & 20 & 42.5 \\
\hline $35-44$ & 13 & 18.9 & 56 & 81.1 & 24 & 51.1 & 23 & 48.9 \\
\hline $45+$ & 9 & 13.2 & 59 & 86.8 & 34 & 34.7 & 64 & 65.3 \\
\hline total & 125 & 37.9 & 205 & 62.1 & 104 & 48.4 & 111 & 51.6 \\
\hline
\end{tabular}

cation and prevention of periodontal disease. $35 \%$ of the non-Amish sample provided the correct response to 8 knowledge questions while only $10 \%$ of the amish could. Over $2 / 3$ of Amish indicated incorrectly that cavities were indicative of periodontal disease and that widening of spaces between teeth was not an indicator. It is important to point out that this lack of knowledge is evident in the reported oral hygiene practices of Amish, who show low behav- ioral scores when asked about actual practices.

Table 5 shows that the proportion of persons with $4 \mathrm{~mm}$ or more of attachment loss rose with age, as expected. A greater proportion of Amish had $4 \mathrm{~mm}$ of attachment loss at every age level. The overall difference in the proportion of respondents with $\geqslant 1$ tooth at the 4 $\mathrm{mm}$ level was $62 \%$ for Amish and $52 \%$ for non-Amish.

Logistic regression showed a high risk for attachment loss of $4 \mathrm{~mm}$ for respondents who were Amish, male, older, had calculus, and knew little about the signs of gum disease $(p<0.05$, Table 6). For pocket depth of $5 \mathrm{~mm}$, the best-fitting model includes Amish, older, male, having calculus, and having gingivitis as significant risk factors. The odds ratios presented in Table 6 show age as being the highest risk factor of $4 \mathrm{~mm}$ of attachment loss. For pocket depth, the greatest risk is among those with gingivitis.

Behavior, plaque, and interactions between the independent variables did not reach statistical significance in the final model for attachment loss or pocket depth. However, when factors related to having gingivitis, calculus, or plaque were examined, interactions and behavior were important. The significant risk factors for plaque are being Amish, older, having little knowledge about the signs of periodontal disease, and the interaction between Amish and behavior (Table 7). Significant factors related to having gingivitis are being Amish, older, having little knowledge about the signs of periodontal disease, behavior, and the interactions between Amish and knowledge of the signs of periodontal disease. No factors were significantly related to having calculus.

When whole mouth means were examined, being Amish, age, and gender (male) were significantly related to attachment loss. These 3 variables constituted the entire set of independent variables for the final model. For mean pocket depth, having gingivitis, being Amish, age, and male were significant risk factors.

\section{Discussion}

The Amish settlements in Michigan present an exceptional opportunity to study demographic factors and behaviors associated with periodontal disease. Amish homes are interspersed among non-Amish, thus reducing environmental influences not related to genetics or life-style on the disease process. The Amish and controls in this study were predominantly farmers.

The examination of different measures of periodontal disease in this study indicates that an assessment of severity when measured as the presence of $\geqslant 1$ site at a specific disease level, yields more information than an assessment of whole-mouth means (Burt 1990). Only Amish, gender, and age were significantly related to mean levels of attachment 
Table 6. Odds ratios for periodontal disease

\begin{tabular}{lccccc}
\hline & \multicolumn{2}{c}{ Attachment loss $\geqslant 4 \mathrm{~mm}$} & & \multicolumn{2}{c}{ Pocket depth $\geqslant 5 \mathrm{~mm}$} \\
\cline { 2 - 3 } \cline { 6 - 6 } & odds ratio & $p$ & & odds ratio & $p$ \\
\hline Amish & 2.27 & 0.0009 & & 1.72 & 0.01 \\
gender & 2.32 & 0.0001 & & 1.65 & 0.01 \\
age (years) & & & & & \\
$\quad 25-34$ & 3.82 & 0.0001 & & 2.29 & 0.005 \\
$35-44$ & 9.12 & 0.0001 & & 1.88 & 0.03 \\
$45+$ & 15.80 & 0.0001 & & 2.08 & 0.01 \\
Plaque & 1.72 & 0.06 & & 1.75 & 0.07 \\
calculus & 2.20 & 0.01 & & 2.32 & 0.003 \\
gingivitis & 1.36 & 0.28 & & 3.00 & 0.0005 \\
behavior & 1.09 & 0.28 & & N/A & N/A \\
disease knowledge & 1.22 & 0.002 & & N/A & N/A \\
\hline
\end{tabular}

* Reference group was respondents $18-24$ years old.

Table 7. Odds ratios for plaque and gingivitis

\begin{tabular}{lccccc}
\hline & \multicolumn{2}{c}{ Plaque } & & \multicolumn{2}{c}{ Gingivitis } \\
\cline { 2 - 3 } \cline { 5 - 6 } \cline { 5 - 6 } & odds ratio & $p$ & & odds ratio & $p$ \\
\hline Amish & 7.1 & 0.02 & & 13.46 & 0.002 \\
gender & 1.27 & 0.20 & & 1.51 & 0.03 \\
age (years)* & & & & \\
$\quad 25-34$ & 1.05 & 0.80 & & 1.25 & 0.40 \\
$35-44$ & 1.22 & 0.50 & & 1.12 & 0.70 \\
$\quad 45+$ & 1.95 & 0.01 & & 1.32 & 0.30 \\
behavior & 1.68 & 0.03 & & 1.63 & 0.04 \\
knowledge score & 1.43 & 0.05 & & 2.05 & 0.001 \\
interactions: & & & & \\
$\quad$ Amish/behavior & 1.39 & 0.03 & & 1.32 & 0.06 \\
$\quad$ Amish/knowledge & 1.17 & 0.21 & & 1.42 & 0.01 \\
\hline
\end{tabular}

* Reference group was respondents 18-24 years old.

loss and pocket depth, whereas severity measured at $\geqslant 1$ site at a specific level showed additional factors as being significant predictors.

Amish respondents reported lower education levels, scored lower on knowledge of signs of periodontal disease, and reported less oral health care than non-Amish. The difference in disease levels, although statistically significant, is clinically small. Overall, Amish respondents had only $0.32 \mathrm{~mm}$ more attachment loss and $0.21 \mathrm{~mm}$ more pocket depth than non-Amish. Differences in plaque, gingivitis, and calculus were also small.

Both measures of periodontal disease, attachment loss of $4 \mathrm{~mm}$ or pocket depth of $5 \mathrm{~mm}$, assessed among Amish and non-Amish respondents, demonstrated the expected relationships with age and gender. The odds of having attachment loss of $4 \mathrm{~mm}$ were higher among persons with calculus and those who knew little about the signs of periodontal disease. The highest odds ratio for pocket depth of $\geqslant 5 \mathrm{~mm}$ was for persons with gingivitis. This may be due to inflammation that occurs with gingi- vitis. A pocket may be measured deeper by the examiner if the area around the tooth is swollen due to gingivitis. Calculus showed the 2nd highest odds ratio for pocket depth. Calculus is formed over a longer period of time than plaque and gingivitis; thus, it is not surprising that calculus was the only measure of the 3 that was a strong predictor of attachment loss and pocket depth.

The high odds ratio between having gingivitis or plaque and being Amish reflect the low behavior score among the Amish (Table 7). It is interesting to note that behavior was not statistically significant for attachment loss or pocket depth and was significant in the plaque and gingivitis models. Levels of plaque and gingivitis in the mouth are affected by brushing or flossing, whereas the connection between oral hygiene and pocket depth or attachment loss is not as straightforward; these results are thus in line with current thought that considers plaque and gingivitis separate entities from the more advanced disease of attachment loss (Williams 1990). Oral health care and knowledge about the signs of periodontal disease were significant risk factors for having plaque along with the interaction effect of oral health care and being Amish. The gingivitis model was similar with being Amish, male, high behavior score, high knowledge score, and the interaction between being Amish and knowledge of periodontal disease as significant.

The modest differences between Amish and non-Amish oral health were interesting given the dramatic differences in oral hygiene practice and knowledge of periodontal disease. A lack of knowledge may well lead to a lack of dental care which is expected to lead to periodontal disease and missing teeth. This study of oral health indicates Amish have slightly more disease than nonAmish, which is in line with the reported lack of knowledge of periodontal disease and poor oral hygiene practices among Amish.

\section{Acknowledgement}

This work was supported by the National Institute of Dental Research Grant 5RO1 DEO8571-01.

\section{Zusammenfassung}

Ein Vergleich von Parodontalerkrankungen zwischen Erwachsenen der ländlichen Amischund Nicht-Amisch Bevölkerung

Parodontalerkrankungen können besser innerhalb einer homogenen Population untersucht werden, in der genetische Einflüsse und Lebensgewohnheiten ähnlich genug sing, um keine Auswirkung auf den Erkrankungsprozeß zu haben. Diese Studie konzentriert sich auf eine Amisch-Bevölkerung im Süden Michigans, die sich selbst äußeren Einflüssen gegenüber isoliert und ihren Nicht-Amisch Nachbarn. Insgesamt wurde mit 425 Amisch und 290 Nicht-Amisch Kontakt aufgenommen. Das Ergebnis war, daß 330 Amisch und 215 Nicht-Amisch bei sich zuhause untersucht wurden, wodurch sich eine Teilnahmerate von $76.2 \%$ ergab. Das Alter lag zwischen 18 und 82 Jahren. Die Prävalenz der Parodontalerkrankung tendierte dazu, bei Männern höher zu sein und im Alter zuzunehmen. Es gab etwas mehr weibliche Amisch- (52\%) als Nicht-amisch (49\%) -Teilnehmerinnen. Die Mittelwerte für den parodontalen $\mathrm{Zu}$ stand für die Amisch-Bevölkerung waren $1.35 \mathrm{~mm}$ für Attachmentverlust, $2.59 \mathrm{~mm}$ für Taschentiefe, 0.24 für Zahnstein, 0.77 für Plaque und 0.74 für Gingivitis. Für die NichtAmisch-Bevölkerung waren die Mittelwerte $1.03 \mathrm{~mm}$ für Attachmentverlust, $2.38 \mathrm{~mm}$ für Taschentiefe, 0.40 für Zahnstein, 0.95 für Plaque und 0.87 für Gingivitis. Es ist von Interesse, daß die Amisch keine regelmäßige Mundhygiene durchführen. Nur 36,8\% der 
Amisch berichteten, daß sie wenigstens einmal pro Tag putzen, im Vergleich zu $84.6 \%$ der Nicht-Amisch. Auch berichteten nur 8.2 der Amisch, daß sie Zahnseide wenigstens einmal pro Woche verwenden, im Vergleich zu 40.8\% der Nicht-Amisch.

\section{Résumé}

Comparaison de la maladie parodontale chez des adultes dans des populations rurales Amish et non-Amish

L'étude de la maladie parodontale peut être plus efficace si elle est faite au sein d'une population homogène où les styles de vie et les influences génétiques sont suffisamment uniformes pour annuler leur effet sur le processus pathologique. La présente étude est centrée sur une population Amish du sud du Michigan qui s'isole des influences extérieures et de leurs voisins non-Amish. On a pris contact avec au total 425 Amish et 290 nonAmish, ce qui a permis d'examiner 330 Amish et 215 non-Amish à leur domicile, obtenant ainsi un taux de participation de $76.2 \%$. Leur âge allait de 18 à 82 ans. La prévalence de la maladie parodontale tendait à être plus élevée chez les sujets du sexe masculin et augmentait avec l'âge. Il y avait un peu plus de sujets du sexe féminin Amish (52\%) que non-Amish (49\%). Les moyennes des paramètres parodontaux chez les Amish étaient $1.35 \mathrm{~mm}$ pour la perte d'attache, $2.59 \mathrm{~mm}$ pour la profondeur des poches, 0.24 pour le tartre, 0.77 pour la plaque et 0.74 pour la gingivite. Chez les non-Amish, ces moyennes étaient $1.03 \mathrm{~mm}$ pour la perte d'attache, $2.38 \mathrm{~mm}$ pour la profondeur des poches, 0.40 pour le tartre, 0.95 pour la plaque et 0.87 pour la gingivite. Il est intéressant de noter que les Amish ne pratiquent pas de soins réguliers d'hygiène bucco-dentaire. Chez les Amish, 36.8\% seulement disaient se brosser les dents au moins une fois par jour, contre $84.6 \%$ chez les nonAmish. De même, $8.2 \%$ des Amish seulement disaient utiliser le fil dentaire au moins une fois par semaine, contre $40.8 \%$ des nonAmish.

\section{References}

Bagramian, R. A., Farghaly, M., Lopatin, D. E., Sowers, M. F., Syed, S. A. \& Pomerville, J. L. (1992) Periodontal disease in an Amish population. Journal of Clinical Periodontology 20, 269-272.

Bagramian, R. A., Narendran, S. \& Khavari, A. M. (1988) Oral health status, knowledge, and practices in an Amish population. Journal of Public Health Dentistry 48, 147-151.

Beck, J. D., Lainson, P. A., Field, H. M. \& Hawkins, B. F. (1984) Risk factors for various levels of periodontal disease and treatment needs in Iowa. Community Dentistry and Oral Epidemiology 12, 17-22.

Brown, J. L., Oliver, R. C. \& Löe, H. (1990) Evaluating periodontal status of US employed adults. Journal American Dental Association 121, 226-232.

Brown, L. J., Oliver, R. C. \& Löe, H. (1989) Periodontal diseases in the U.S. in 1981: prevalence, severity, extent, and role in tooth mortality. Journal of Periodontology 60, 363-370.

Burt, B. A., Ismail, A. I., Morrison, E. C. \& Beltran, E. D. (1990) Risk factors for tooth loss over a 28-year period. Journal of Dental Research 69, 1126-1130.

Epidemiology and Oral Disease Prevention Program N (1988) Oral health of United States adults: the National survey of oral health in US employed adults and seniors, 1985-86: regional findings. NIH publication no. 87-2869.

Epidemiology and Oral Disease Prevention Program N (1987) Oral health of United States adults: the National survey of oral health in US employed adults and seniors, 1985-86: national findings. NIH publication no. 87-2868.

Hostetler, J. A. (1980) Amish society, 3rd edition. Baltimore, MD: John Hopkins University Press.

Ismail, A. I., Morrison, E. C., Burt, B. A., Caffesse, R. G. \& Kavanagh, M. T. (1990)
Natural history of periodontal disease in adults: findings from the Tecumseh periodontal disease study, 1959-1987. Journal of Dental Research 69, 430-435.

Kingman, A., Morrison, E., Löe, H. \& Smith, J. (1988) Systematic errors in estimating prevalence and severity of periodontal disease. Journal of Periodontal Research 59, 707-713.

Löe, H., Age, A., Hans, B. \& Martyn, S. (1978) The natural history of periodontal disease in man. The rate of periodontal destruction before 40 years of age. Journal of Periodontology 49, 607-620.

Löe, H., Anerud, A., Boysen, H. \& Morrison, E. (1986) Natural history of periodontal disease in man: rapid, moderate and no loss of attachment in Sri Lankan laborers 14 to 46 years of age. Journal of Clinical Periodontology 13, 431-445.

Löe, H. \& Silness, J. (1963) Periodontal disease in pregnancy (I). Prevalence and severity. Acta Odontologica Scandinavica 21, 533-551.

McKusick, V. A. (1980) The Amish. Endeavor 4, 52-57.

Ramfjord, S. P. (1976) The periodontal disease index (PDI). Journal of Periodontology 38, 602-611.

Sillness, J. \& Löe, H. (1964), Periodontal disease in pregnancy (II). Correlation between oral hygiene and periodontal condition. Acta Odontologica Scandinavica 22, 121-135.

Williams, Ray C. (1990) Periodontal disease. The New England Journal of Medicine 322, 373-381.

Address:

R. A. Bagramian

Department of Periodontics/Prevention and Geriatrics

School of Dentistry, University of Michigan Ann Arbor, Michigan 48109-1078

Supported by National Institue of Dental

Research. 5R01 DE08571-01

USA 
This document is a scanned copy of a printed document. No warranty is given about the accuracy of the copy. Users should refer to the original published version of the material. 